\title{
Cichorium intybus from India: GC-MS Profiling, Phenolic Content and in vitro Antioxidant Capacity of Sequential Soxhlet Extracted Roasted Roots
}

\author{
Ravinder Singh ${ }^{1^{*}}$ \\ https://orcid.org/0000-0001-7511-959X \\ Khushminder Kaur Chahal ${ }^{1}$ \\ https://orcid.org/0000-0002-7503-9108
}

${ }^{1}$ Punjab Agricultural University, Department of Chemistry, Ludhiana, Punjab, India

Received: 2018.07.20; Accepted: 2019.06.22

*Correspondence: ravindersadeora@gmail.com, ravinders@pau.edu; Tel.: +91-9809400069 (R.S.)

\section{HIGHLIGHTS}

- The chicory roots possessed antioxidant property even in roasted form.

- The roasted roots are rich source of total phenolics and flavonoids

- Antioxidant activity show a positive relation with total phenolics and flavonoids content

- Methanol was best solvent for extraction of chicory roots for studied parameters

\begin{abstract}
Research on the bio-activities and chemical composition of roasted C. intybus roots from India is very little. In present studies GC-MS analysis of volatile components of roasted C. intybus roots, phenolics and flavonoid content estimation and antioxidant potential of roasted $\mathrm{C}$. intybus roots was carried out. Antioxidant potential was also evaluated using FRAP, DPPH, hydroxyl radical, nitric oxide and superoxide free radical scavenging method. Extracts were prepared by sequential Soxhlet extraction. GC-MS analysis of volatile components of roasted C. intybus root extracts revealed that 5hydroxymethyl furfural was major volatile component in dichloromethane and methanol extract whereas lupeol and its derivative compounds were major constituents of hexane extract. Quantitative estimation for total phenols and flavonoids showed that the methanol extract of $C$. intybus roots contained highest phenolic and flavonoid content as compared to other extracts and also showed strong radical scavenging activities which were comparable with ascorbic acid used as standard. All extracts showed $I_{50}$ values less than $0.6 \mathrm{mg} / \mathrm{mL}$ furthermore, extracts of roasted $\mathrm{C}$. intybus showed the high total antioxidant potential for the reduction of $\mathrm{Fe}^{3+}$ to $\mathrm{Fe}^{2+}$. The $\mathrm{C}$. intybus roots possess good antioxidant capacity even after roasting and all the extracts showed good activities.
\end{abstract}


Keyword Antioxidant potential; Chicory; Chemical Composition; Solvent extracts.

\section{INTRODUCTION}

Cichorium intybus L. also known as chicory, is a plant belonging to Asteraceae family. Roasted $C$. intybus roots are used as coffee substitute in many coffee-like beverages [1]. Roasted $C$. intybus powder has been widely used in coffee blends, since many coffee drinkers prefer its distinct flavour ${ }^{1}$. It enhances the colour, flavour and aroma of beverages [2]. In Germany it is sold as a constituent of mixtures with roasted barley malt. Roots of $C$. intybus are used for the production of inulin and as ingredients in certain roasted products [3]. C. intybus also have an economic importance in many regions of the world [4]. The crop has potential as a biomass crop for industrial use as the plant bears tuberous roots which store inulin that can easily be converted to alcohol [5]. Hui et al. [6] reported use of inulin as a food ingredient for fat and sugar replacement as a low calorie bulking and texturizing agents. C. intybus also possess importance as forage crop, raw material for fructose and as a feed additive. $C$. intybus roots are also used in salads, as a chewing gum and in spice production [7]. C. intybus $(100 \mathrm{~g})$ could provide good amount of total polyphenols i.e. up to $400 \mathrm{mg}$, to the human diet [8]. C. intybus gained attention due to its phytochemical contents having nutraceutical potential [9]. It contained phytochemicals like flavonoids, cinnamic and quinic acid derivatives, coumarin, and anthocyanins. In addition to these $C$. intybus was reported contained compounds such as alkaloids, inulin, sesquiterpene lactones, vitamins, chlorophyll pigments, unsaturated sterols, saponins, and tannins with putative health benefits also [10].

C. intybus plant possess a wide variety of bioactivities and multiple research papers have been published describing the phytochemical composition and several health properties of $C$. intybus, including antidiabetic, hyperglycemic, wound healing and antioxidant capacities of different parts of $C$. intybus plant [11-15]. Change in antioxidant potential of chicory leaves after treatment with different drying method is recently reported by $\mathrm{Li}$ et al. [12]. Most of the work was carried out on fresh plant parts or their water extracts only. But the evaluation of solvent extracts especially of roasted parts of $C$. intybus plant is less. The study of literature revealed that work regarding bioactivity and composition of widely consumed roasted roots of $C$. intybus is very less. In present studies GC-MS analysis, estimation of total phenolic and flavonoid contents of different extracts of roasted $C$. intybus root powder and their antioxidant activity using various in vitro models was undertaken.

\section{MATERIAL AND METHODS}

\section{Chemicals and reagents}

2,2-diphenyl-1-picrylhydrazyl, 2,4,6-tripyridyl-s-triazine, acetic acid, aluminium chloride, ascorbic acid, deoxyribose, ferric chloride, dichloromethane, ethylene diamine tetraacetic acid, ferrous sulfate, Folin-Ciocalteu reagent, gallic acid, Hydrogen-peroxide, hexane methanol, monobasic and dibasic potassium phosphate, naphtyl ethylene diamine dihydrochloride, nicotinamide adenine dinucleotide, nitro blue tetrazolium, phenazine methoxy sulphate, phosphoric acid, potassium acetate, quercetin, sodium acetate, sodium carbonate, sodium nitroprusside, sulphanilamide and thiobarbituric acid.

\section{Preparation of extracts}

C. intybus roots $(1 \mathrm{~kg})$ were cut into small pieces and oven dried at $150^{\circ} \mathrm{C}$ until it turn brown. Extracts were prepared using sequential Soxhlet extraction method. The roasted pieces were powdered in grinder and extracted with different solvents. The roasted $C$. intybus root powder $(100 \mathrm{~g}$ ) was packed in a thimble and subjected to Soxhlet apparatus and extracted sequentially with solvents $(250 \mathrm{~mL})^{16}$ i.e. hexane, dichloromethane and then 
methanol. Refluxing was carried out for $12 \mathrm{~h}$ for each solvent. Distilling off the solvents in round bottom flask gave crude extracts. The extracts were stored at $4^{\circ} \mathrm{C}$.

\section{Gas chromatography-mass spectrometry analysis}

Roasted C. intybus root extracts were analysed using gas chromatography-mass spectrometry (QP2010 Plus, Shimadzu, Japan), equipped with a Rtx-5 MS capillary column (30.0 m x $0.20 \mathrm{~mm}$ i.d., $0.25 \mu \mathrm{m}$ film thickness) for the separation of the components. Injector, kept at $290^{\circ} \mathrm{C}$, was operated in split injection mode and the split valve was closed for $1 \mathrm{~min}$. Carrier gas used was helium gas at a constant pressure of $69 \mathrm{kPa}$. The column oven was maintained at $100{ }^{\circ} \mathrm{C}$ for $1 \mathrm{~min}$ initially and then elevated at $2.5^{\circ} \mathrm{C} / \mathrm{min}$ to $220^{\circ} \mathrm{C}$, then at $5{ }^{\circ} \mathrm{C} / \mathrm{min}$ to $300^{\circ} \mathrm{C}$. The ionization mode was electron impact $(70 \mathrm{eV})$ and interface temperature was $260^{\circ} \mathrm{C}$. The mass selective detector worked in the scan mode from 40 and $800 \mathrm{~m} / \mathrm{z}$. After $3.0 \mathrm{~min}$ of injection data acquisition was started. Parameters used in mass spectrometer were; Ionization voltage (El) which was $70 \mathrm{eV}$, peak width was $2 \mathrm{~s}$, mass range was 40-800 amu and detector voltage was $0.89 \mathrm{kV}$. Identification of peaks was done by comparing the mass spectra with mass spectra data available on database of NIST08, WILEY8, Perfumery and Flavor and Fragrance libraries.

\section{Estimation of total phenolic and flavonoid contents}

Total phenolic content was determined according to Follin-Ciocalteu method [17]. In 100 $\mu \mathrm{l}$ of each concentration of standard solution, $100 \mu \mathrm{l}$ of Folin-Ciocalteu reagent and $2 \mathrm{ml}$ of $2 \%$ sodium carbonate $\left(\mathrm{Na}_{2} \mathrm{CO}_{3}\right)$ were mixed. The resulting mixture was allowed to stand at room temperature for $30 \mathrm{~min}$ and the absorbance was measured at $743 \mathrm{~nm}$ using UV-Visible Spectrophotometer against a blank prepared similarly but containing distilled water instead of standard solution of gallic acid. A standard curve was obtained by plotting absorbance against amount of gallic acid. A standard (calibration) curve was obtained by plotting the absorbance at $743 \mathrm{~nm}$ against various concentration of gallic acid.

Estimation of total flavonoids in extracts of $C$. intybus roots was done by method prescribed by Eom et al. [18]. In extracts $(0.5 \mathrm{ml}) 0.1 \mathrm{ml}$ of $10 \%$ aluminium chloride and 0.1 $\mathrm{ml}$ of potassium acetate $(1 \mathrm{M})$ were added. In this mixture $4.3 \mathrm{ml}$ of $80 \%$ methanol was added to make $5 \mathrm{ml}$ volume. The absorbance was measured against a blank containing respective solvent without extracts at $415 \mathrm{~nm}$ using UV-VIS double beam spectrophotometer. The amount of total flavonoids present in the extracts was calculated from the standard curve of quercetin and results were expressed as milligrams of quercetin equivalent per gram ( $\mathrm{mg} \mathrm{QE} \mathrm{g}^{-1}$ ).

\section{Antioxidant capacity analysis}

The antioxidant capacity was evaluated using five different in vitro models involving ferric reducing antioxidant power assay (FRAP), 2, 2-diphenyl-1-picrylhydrazyl (DPPH'), nitric oxide (NO), hydroxyl $\left(\mathrm{OH}^{\circ}\right)$, Superoxide radical $\left(\mathrm{O}_{2}{ }^{\circ}\right)$ scavenging methods.

\section{Ferric reducing antioxidant power}

Ferric reducing antioxidant power (FRAP) of various extracts were determined using method given by Benzie \& Strain [19]. The fresh working FRAP solution was prepared by mixing $25 \mathrm{~mL}$ acetate buffer $(300 \mathrm{mM}, \mathrm{pH}-3.6), 2.5 \mathrm{~mL}$ 2, 4, 6-tripyridyl-s-triazine $(10 \mathrm{mM})$ and $2.5 \mathrm{~mL}$ hydrated ferric chloride $(20 \mathrm{mM})$. The FRAP solution was heated to $37^{\circ} \mathrm{C}$ before use. Extracts $(0.2 \mathrm{~mL})$ were mixed with $2.8 \mathrm{~mL}$ of the FRAP solution and allowed to react for $30 \mathrm{~min}$ in the dark condition. Coloured product was read at $593 \mathrm{~nm}$. Results were expressed in terms of $\mu \mathrm{mol}$ of $\mathrm{Fe}(\mathrm{II}) / \mathrm{mL}$ of extract.

\section{DPPH radical scavenging method}

2, 2-diphenyl-1-picrylhydrazyl (DPPH) radical scavenging of all the extracts were 
determined [20]. To $1 \mathrm{~mL}$ of various concentrations $(0.05-1.0 \mathrm{mg} / \mathrm{mL})$ of test extracts dissolved in methanol, $1 \mathrm{~mL}$ DPPH solution $(0.1 \mathrm{mM})$ in methanol was added. The colour of reaction mixture was read at $517 \mathrm{~nm}$ using UV-spectrophotometer after keeping the reaction mixture in dark 30 min at room temperature. Ascorbic acid was used as a reference material. All tests were performed in triplicate. The percentage inhibition was determined by comparing the absorbance values of tested components and control using the formula

Percentage inhibition $(\%)=\frac{\text { Absorbance of control - Absorbance of sample }}{\text { Absorbance of control }} \times 100$

\section{Hydroxyl radical $(\bullet \mathrm{OH})$ scavenging method}

Hydroxyl radical $\left({ }^{\circ} \mathrm{OH}\right)$ scavenging activity was determined by deoxyribose-degradation method [21]. A mixture containing ascorbic acid $(0.1 \mathrm{mM})$, deoxyribose $(2.8 \mathrm{mM})$, ethlene diamine tetraacetic acid $(0.1 \mathrm{mM})$, ferric chloride $(0.1 \mathrm{mM})$, hydrogen peroxide $(1 \mathrm{mM})$, phosphate buffer $(20 \mathrm{mM}, \mathrm{pH} 7.4)$ was various concentrations of extracts in a final volume of $1 \mathrm{~mL}$. The reaction mixture was incubated for $1 \mathrm{hr}$ at $30{ }^{\circ} \mathrm{C}$. For this, $3 \mathrm{~mL}$ thiobarbituric acid $(0.67 \%)$ was added to each test tube and kept for $1 \mathrm{hr}$ in boiling water. The absorbance of the chromophore formed was read at $532 \mathrm{~nm}$ against blank prepared in similar way. Control was also run parallel, in which no compound was added. The percentage inhibition was calculated using same formula given above.

\section{Nitric oxide (NO') scavenging method}

Nitric oxide radical scavenging of all the extracts of $C$. intybus roots were determined [22]. In a test tube $0.5 \mathrm{~mL}$ volume of various concentrations $(0.05-1 \mathrm{~g} / \mathrm{mL})$ of extracts, $0.5 \mathrm{~mL}$ of sodium nitroprusside $(10 \mathrm{mM})$ and $0.5 \mathrm{~mL}$ phosphate buffered saline were added followed by incubation at $30^{\circ} \mathrm{C}$ for $2.5 \mathrm{hrs}$. After incubation, $1 \mathrm{~mL}$ of freshly prepared Gries reagent was added. The absorbance of chromophore formed was read at $548 \mathrm{~nm}$ against blank after making the final volume of $3 \mathrm{~mL}$ with distilled water. The percentage inhibition of nitric oxide generation was calculated using same formula given above.

\section{Superoxide radical $\left(\mathrm{O}_{2}{ }^{\circ}\right)$ scavenging activity}

Superoxide radical scavenging was based on the method described by Liu et al. [23]. Tested extract $(1 \mathrm{~mL})$ was mixed with $1 \mathrm{~mL}$ of phosphate buffer $(\mathrm{pH} 7.4)$ containing $1 \mathrm{~mL}$ of NBT $(50 \mu \mathrm{M})$ solution, $1 \mathrm{~mL}$ of NADH $(78 \mu \mathrm{M})$ solution. To this mixture $1 \mathrm{~mL}$ of phenazine methoxy sulfatenicotinamide solution $(60 \mu \mathrm{M})$ was added to initiate the reaction. The colour of reaction mixture was read after incubating it at $25^{\circ} \mathrm{C}$ for $5 \mathrm{~min}$ at $560 \mathrm{~nm}$ against blank samples using UV-spectrophotometer. The percentage inhibition was calculated using same formula given above.

\section{Statistical analysis}

Experimental results were mean \pm standard deviation of three parallel measurements and analysed using software SAS 9.4. Differences between mean were determined using Tukey multiple range test and correlations were obtained by Pearson correlation coefficient. $P$ values less than 0.05 were regarded significant.

\section{RESULTS AND DISCUSSION}

Roots of $C$. intybus were extracted sequentially with solvents of increasing polarity viz hexane, dichloromethane, methanol in order to characterise all type of volatile components present in roots. The hexane soluble components present in root powder were extracted with hexane. Further same powder was extracted with dichloromethane thus component which were not soluble in hexane but soluble in dichloromethane were extracted and the components not soluble in hexane or dichloromethane were extracted out with methanol which was the most polar solvent used for extraction. 


\section{Gas chromatography-mass spectrometry analysis}

Gas chromatography-mass spectrometry analysis of volatile components revealed that maximum number of volatile compounds present in $C$. intybus root powder were hexane soluble i.e. 35 compounds that were present in hexane extract. Dichloromethane soluble compounds were 25 and while methanol extract contained only 20. Components present in different extracts were mostly different except a few e.g. 5-Hydroxymethyl furfural (HMF). HMF was found to be the major component in dichloromethane and methanol extract whereas lupeol, a bioactive triterpene and its derivatives were found to be major constituents of hexane extract. GC-MS analysis of all the extracts is tabulated in Table 1. HMF, the major component have a strong caramellic to burnt sugar fragrance. Many studies showed the presence of 5-hydroxyl methyl furfural in coffee powder. HMF was reported to form during the roasting of coffee and the concentration in different commercially available roasted coffee was found to be different [24]. Presence HMF in $C$. intybus extract can be attributed to the strong and coffee like flavour of $C$. intybus. HMF was not reported as major constituent of roasted $C$. intybus root powder by some researchers. Majcher et al. [25] showed 2methoxy phenol, 2,3-butanedione, 2-furfurylthiol, 2-thenylthiol as major volatile component of roasted $C$. intybus. Whereas 1-octene-3-one, 2-ethyl-3,5-dimethylpyrazine, 3-methylbutanal and 2,3- butanedione were reported as the most odour active compounds of roasted $C$. intybus using using dynamic headspace and simultaneous steam-distillation-solvent extraction [2]. C. intybus roots are well-known to contain inulin, a polymer of sugar molecules. Fachri et al. [26] reported the estimation of thermal conversion of inulin of $C$. intybus roots to HMF and derivatives.

HMF is practically present in every food containing free carbohydrates with amount up to $0.08 \mathrm{mg} / \mathrm{g}$. But presence of high content of HMF in roasted $C$. intybus is a big concern as roasted $C$. intybus powder is widely consumed in India as coffee substitute as well as an adulterant in coffee and various studies on the metabolic activation of HMF showed a genotoxic potential of this compound [27, 28]. However, the acute toxicity of HMF was relatively low and the $\mathrm{LD}_{50}$ was shown to be $3.1 \mathrm{~g} / \mathrm{kg}$ bw in rats [29]. The genotoxic and carcinogenic potential reviewed by Janzowski et al. [30] showed that HMF was not a highly dangerous compound. HMF was metabolised in the kidneys to 5-Hydroxy-methyl-2-furoic acid and other compounds which was then excreted with the urine. This was shown for rats and mice [31] as well as humans [32]. Thus some reported HMF as genotoxic molecule and other not thus it is not clear whether HMF is genotoxic or not but still it is a good starting material for the synthesis of precursors of various pharmaceuticals, thermo-resistant polymers and complex macrocyclic molecules. Due to the natural source, roasted $C$. intybus roots are good and cheap source for HMF.

\section{Estimation of total phenolic and flavonoid content}

Total phenolic and flavonoid contents in extracts of $C$. intybus roots were also evaluated (Table 2). The amount of total phenolic content was found to be highest in methanol extract and least in hexane extract. Similar trend was observed in case of flavonoid content also.Total phenolic contents in extracts varied from 0.68 to $10.13 \mathrm{mg} \mathrm{GAE} / \mathrm{g}$ of root powder. The amount of flavonoids in extract varied from 0.73 to $8.8 \mathrm{mg} \mathrm{QE} / \mathrm{g}$ of root powder. As roasted $C$. intybus root powder was sequentially extracted so actual total phenolic and flavonoid content was sum of content in all extracts i.e. phenolic content of $C$. intybus root powder was $15.01 \mathrm{mg} \mathrm{GAE} / \mathrm{g}$ powder and flavonoid content was $13.82 \mathrm{QE} / \mathrm{g}$ powder. As content of both components was maximum in methanol extract thus it can be concluded that maximum phenolics and flavonoid present in roasted $C$. intybus roots were methanol soluble. The results of present studies were found to be in agreement with Felhi et al. [33] who reported methanol as the best solvent for extraction of total phenolics and flavonoid content. Baeza et al. [34] reported total phenolic content in C. intybus coffee was aprox. 22 $\mathrm{mg} \mathrm{GAE} / \mathrm{g}$ of $C$. intybus coffee which was near to content observed in present study. 
Table 1. GC-MS analysis of different solvent extracts of $C$. intybus roots

\begin{tabular}{|c|c|c|c|c|c|c|c|c|c|}
\hline \multirow[b]{2}{*}{ Sr.No. } & \multicolumn{3}{|l|}{ Hexane extract } & \multicolumn{3}{|c|}{ Dichloromethane extract } & \multicolumn{3}{|c|}{ Methanol extract } \\
\hline & Compounds & $\begin{array}{l}\text { Retention } \\
\text { time }\end{array}$ & Area \% & Compounds & $\begin{array}{l}\text { Reten } \\
\text { tion } \\
\text { time }\end{array}$ & Area \% & Compounds & $\begin{array}{l}\text { Retention } \\
\text { time }\end{array}$ & Area \% \\
\hline 1 & Undec-3-en-2-ol & 2.145 & 0.51 & 2-furancarboxaldehyde & 2.378 & 0.56 & Glyceraldehyde & 2.353 & 9.60 \\
\hline 2 & 2-Nitrohexane & 2.945 & 0.56 & Caprolactone & 3.058 & 0.84 & $\begin{array}{l}\text { 4-Hydroxy-4-methyl-2- } \\
\text { pentanone, }\end{array}$ & 2.422 & 3.20 \\
\hline 3 & 2,2-Dimethyl-pentan-1-ol & 3.148 & 0.40 & $\begin{array}{l}\text { 4-oxo-5-methoxy-2-penten- } \\
\text { 5-olide }\end{array}$ & 3.516 & 1.39 & $\beta$-Ketoglutaric acid & 2.725 & 2.41 \\
\hline 4 & $\begin{array}{l}\text { 5-Methyl-2- } \\
\text { furancarboxaldehyde }\end{array}$ & 3.646 & 0.81 & Maltol & 6.774 & 0.70 & Dihydroxyacetone & 2.879 & 4.35 \\
\hline 5 & 3-Hexen-2-one & 3.698 & 0.54 & 3-hydroxy-2,3-dihydromaltol & 6.845 & 1.64 & Hydracrylic acid & 2.972 & 1.10 \\
\hline 6 & 5-Hexen-2-one & 4.888 & 0.42 & methyl 2,4-heptadienoate & 6.957 & 0.65 & Glycerine & 3.724 & 5.65 \\
\hline 7 & Maltol & 6.171 & 0.45 & $\begin{array}{l}24 \text {-hydroxydihydro-2(3h)- } \\
\text { furanone }\end{array}$ & 7.432 & 0.87 & $\begin{array}{l}\text { 2,4-Dihydroxy-2,5-dimethyl- } \\
\text { 3(2h)-furan-3-one }\end{array}$ & 3.916 & 1.50 \\
\hline 8 & 5-Hydroxymethylfurfural & 8.673 & 2.69 & $\begin{array}{l}\text { 2-methyl-2h-pyran- } \\
\text { 3,4,5(6h)-trione }\end{array}$ & 7.757 & 5.92 & 1,3,5-Triazine-2,4,6-triamine & 5.470 & 3.13 \\
\hline 9 & 2-Acetyl-resorcinol & 9.671 & 0.45 & $\begin{array}{l}\text { 4-(1-hydroxy-ethyl) .gamma. } \\
\text { butanolactone }\end{array}$ & 8.031 & 0.74 & Unknown & 5.659 & 1.00 \\
\hline 10 & $\begin{array}{l}\text { 5-Acetoxymethyl-2- } \\
\text { furaldehyde }\end{array}$ & 10.328 & 1.42 & 5-hydroxymethylfurfural & 8.853 & 62.35 & 1, 2-Epoxy-3-hydroxypropane & 6.728 & 3.47 \\
\hline 11 & Hexadecanoic acid & 23.636 & 4.69 & $\begin{array}{l}\text { 1,2-cyclohexanedicarboxylic } \\
\text { acid, 4-methoxyphenyl nonyl } \\
\text { ester }\end{array}$ & 9.180 & 0.71 & $\begin{array}{l}\text { 2,3-Dihydro-3,5-dihydroxy-6- } \\
\text { methyl-4h-pyran-4-one }\end{array}$ & 6.835 & 4.29 \\
\hline 12 & Ethyl hexadecanoate & 23.887 & 0.75 & $\begin{array}{l}\text { 4-[(2,6- } \\
\text { dichlorophenyl)methoxy]-3- } \\
\text { ethoxy- benzaldehyde, }\end{array}$ & 9.699 & 1.34 & 5-Hydroxymethylfurfural & 8.598 & 40.50 \\
\hline 13 & Methyl linoleate & 25.543 & 0.47 & $\begin{array}{l}\text { 5-(hydroxymethyl)-2- } \\
\text { (dimethoxymethyl) furan }\end{array}$ & $\begin{array}{l}10.04 \\
1\end{array}$ & 8.99 & Unknown & 13.329 & 6.08 \\
\hline
\end{tabular}




\begin{tabular}{|c|c|c|c|c|c|c|c|c|c|}
\hline 14 & Ambrosial & 26.385 & 1.04 & $\begin{array}{l}\text { 5-acetoxymethyl-2- } \\
\text { furaldehyde }\end{array}$ & $\begin{array}{l}10.32 \\
8\end{array}$ & 0.63 & Unknown & 13.410 & 1.33 \\
\hline 15 & $\begin{array}{l}\text { Ethyl octadec- } 9,12- \\
\text { dienoate }\end{array}$ & 26.620 & 5.91 & $\begin{array}{l}\text { dimethyl } 2,5- \\
\text { thiophenedicarboxylate }\end{array}$ & $\begin{array}{l}10.86 \\
1\end{array}$ & 2.13 & Unknown & 22.056 & 1.57 \\
\hline 16 & Unknown & 26.725 & 1.44 & $\begin{array}{l}\text { 1,2-cyclohexane } \\
\text { dicarboxylic }\end{array}$ & $\begin{array}{l}12.57 \\
8\end{array}$ & 0.67 & Alantolactone & 22.526 & 2.12 \\
\hline 17 & $\begin{array}{l}5 \text {-formyl-2-furyl)methyl } \\
\text { acetate }\end{array}$ & 37.215 & 0.43 & 2,4-di-tert-butylphenol & $\begin{array}{l}14.74 \\
0\end{array}$ & 1.16 & Isoalantolactone & 23.238 & 1.37 \\
\hline 18 & Squalene & 38.582 & 0.44 & 1-octadecene & $\begin{array}{l}16.45 \\
0\end{array}$ & 0.69 & Hexadecanoic & 23.368 & 2.99 \\
\hline 19 & $\begin{array}{l}2-[1- \\
\text { (Hhydroxymethyl)cyclohex } \\
\text { yl] ethanol }\end{array}$ & 39.570 & 0.59 & nonadecyl alcohol & $\begin{array}{l}20.35 \\
5\end{array}$ & 0.81 & Dehydrocostus lactone & 23.987 & 3.31 \\
\hline 20 & Stigmasterol & 44.543 & 0.81 & $\begin{array}{l}\text { 4-(acetylamino)- } 1 \mathrm{~h} \text { - } \\
\text { imidazole-5-carboxamide }\end{array}$ & $\begin{array}{l}21.68 \\
6\end{array}$ & 0.59 & Methyl linoleate & 25.541 & 1.04 \\
\hline 21 & $\begin{array}{l}\delta \text {-Friedoolean-14-en-3- } \\
\text { one }\end{array}$ & 45.488 & 0.99 & palmitic acid & $\begin{array}{l}23.39 \\
5\end{array}$ & 0.72 & & & \\
\hline 22 & Stigmast-5-en-3-ol & 45.695 & 1.53 & $\begin{array}{l}5,5^{\prime} \text {-(oxydimethylene)di- 2- } \\
\text { furaldehyde }\end{array}$ & $\begin{array}{l}23.84 \\
9\end{array}$ & 3.55 & & & \\
\hline 23 & $\beta$-amyrin & 46.574 & 8.96 & 1-octadecene & $\begin{array}{l}23.91 \\
0\end{array}$ & 0.92 & & & \\
\hline 24 & Unknown & 46.785 & 0.70 & $\begin{array}{l}\text { 8-ethenyl-3,4,4a,5,6,7,8,8a- } \\
\text { octahydro-5-methylene-2- } \\
\text { naphthalenemethanol }\end{array}$ & $\begin{array}{l}24.00 \\
0\end{array}$ & 0.78 & & & \\
\hline 25 & Unknown & 47.601 & 13.09 & Lignocerol & $\begin{array}{l}27.15 \\
6\end{array}$ & 0.64 & & & \\
\hline 26 & $\alpha$-amyrin & 47.771 & 2.05 & & & & & & \\
\hline 27 & Stigmast-4-en-3-one & 48.320 & 1.37 & & & & & & \\
\hline 28 & Unknown & 48.797 & 2.88 & & & & & & \\
\hline 29 & Lup-20(29)-en-3-yl acetate & 49.599 & 18.59 & & & & & & \\
\hline 30 & Clerodol & 49.909 & 6.54 & & & & & & \\
\hline 31 & Unknown & 50.745 & 0.98 & & & & & & \\
\hline 32 & Unknown & 50.966 & 1.74 & & & & & & \\
\hline 33 & Unknown & 51.263 & 1.62 & & & & & & \\
\hline
\end{tabular}


Gorjanovic et al. [35] reported unusually high content of phenolics i.e. $5.31 \mathrm{~g} \mathrm{GAE} /$ litre in brew prepared from roasted $C$. intybus powder purchased from local market of Serbia which was quite high. Thus roasted $C$. intybus powder is a good source of phenolics and flavonoids.

Table 2. Total phenolic and flavonoid content of various extracts

\begin{tabular}{llll}
\hline Components & Yield (\%) & $\begin{array}{l}\text { Total phenols } \mathbf{~ m g} \\
\text { GAE/g of root }\end{array}$ & $\begin{array}{l}\text { Total flavonoids } \\
\text { mg QE/g of root }\end{array}$ \\
\hline $\begin{array}{l}\text { Methanol extract } \\
\begin{array}{l}\text { Dichloromethane } \\
\text { extract }\end{array}\end{array}$ & $10.1 \pm 1.2$ & $10.13 \pm 2.01$ & $8.8 \pm 1.97$ \\
Hexane extract & $5.6 \pm 0.8$ & $4.20 \pm 0.42$ & $4.24 \pm 1.62$ \\
\hline
\end{tabular}

Results were expressed as mean \pm SD.

\section{Antioxidant activity}

In order to obtain information regarding antioxidant capacity of activity of roasted $C$. intybus root powder multiple antioxidant assays were performed. Antioxidant capacity of different $C$. intybus extracts prepared by sequential Soxhlet extraction was evaluated by FRAP (Table 3), DPPH, hydroxyl, nitric oxide and super oxide radical scavenging (Table 4). Statistical analysis of data showed that there is significant difference in activities of different extracts. Methanol extract was found to be significantly more active as compared to other extracts. There is no significant difference in activity of methanol extract and ascorbic acid which used as standard.

Table 3. Ferric reducing antioxidant power of various extracts of $C$. intybus roots

\begin{tabular}{lll}
\hline Components & Concentrations $(\mathbf{m g} / \mathbf{m L})$ & Frap value $(\mu \mathrm{mol} / \mathbf{m L})$ \\
\hline & 0.05 & $169.08 \pm 3.21$ \\
Methanol extract & 0.1 & $284.95 \pm 6.36$ \\
& 0.25 & $716.81 \pm 12.8$ \\
& 0.5 & $1005.45 \pm 9.64$ \\
& 1.0 & $1605.45 \pm 9.64$ \\
& Mean & $756.35^{\mathrm{a}}$ \\
\hline \multirow{5}{*}{ Dichloromethane extract } & 0.05 & $173.63 \pm 3.21$ \\
& 0.1 & $266.805 \pm 6.44$ \\
& 0.25 & $557.725 \pm 6.42$ \\
& 0.5 & $848.64 \pm 6.42$ \\
Hexane extract & 1.0 & $1475.90 \pm 6.43$ \\
& Mean & $664.54^{\mathrm{b}}$ \\
\hline & 0.05 & $87.27 \pm 3.21$ \\
& 0.1 & $191.82 \pm 3.22$ \\
& 0.25 & $337.275 \pm 9.65$ \\
& 0.5 & $758.155 \pm 12.24$ \\
& 1.0 & $1126.35 \pm 12.23$ \\
\hline
\end{tabular}

Results were expressed as mean \pm SD.

Mean values followed by same letter are non-significantly different ( $p>0.05)$ according to Tukey multiple range test

In ferric reducing antioxidant power (FRAP) assay it was found that there is significant positive correlation between FRAP value and concentration of extract. Statistical analysis revealed that methanol extract is significantly more active than other tested extracts. Rajukar \& Hande [36] reported a positive correlation between FRAP value and total phenolic content. Thus high FRAP value of methanol extract can be related to the high phenolics and flavonoid content of methanol extract. Antioxidant agents with high scavenging activity showed a low $\mathrm{IC}_{50}$ value [37]. The overall order of activity of tested extracts on the basis of 
$\mathrm{IC}_{50}$ values in decreasing order is as follows: Ascorbic acid > Methanol extract > Dichloromethane extract $>$ Hexane extract 
Table 4. Antioxidant activities of $C$. intybus root extracts using various in vitro models

\begin{tabular}{|c|c|c|c|c|c|c|c|c|c|}
\hline \multirow{2}{*}{ Components } & \multirow{2}{*}{$\begin{array}{l}\text { Concentration } \\
\text { s (mg/mL) }\end{array}$} & \multicolumn{2}{|c|}{$\begin{array}{l}\text { DPPH radical } \\
\text { scavenging }\end{array}$} & \multicolumn{2}{|c|}{$\begin{array}{l}\text { Hydroxyl radical } \\
\text { scavenging }\end{array}$} & \multicolumn{2}{|c|}{$\begin{array}{l}\text { Nitric oxide radical } \\
\text { scavenging }\end{array}$} & \multicolumn{2}{|c|}{$\begin{array}{c}\text { Superoxide radical } \\
\text { scavenging }\end{array}$} \\
\hline & & Inhibition (\%) & $\begin{array}{l}I_{50} \\
(\mathrm{mg} / \mathrm{mL})\end{array}$ & Inhibition (\%) & $\begin{array}{l}I_{50} \\
(\mathrm{mg} / \mathrm{mL})\end{array}$ & Inhibition (\%) & $\begin{array}{l}I_{50} \\
(\mathrm{mg} / \mathrm{mL})\end{array}$ & Inhibition (\%) & $\begin{array}{l}I_{50} \\
(\mathrm{mg} / \mathrm{mL})\end{array}$ \\
\hline Methanol extract & $\begin{array}{c}0.05 \\
0.1 \\
0.25 \\
0.5 \\
1.0 \\
\text { Mean }\end{array}$ & $\begin{array}{c}39.75 \pm 0.11 \\
51.21 \pm 0.11 \\
72.50 \pm 0.11 \\
95.32 \pm 0.23 \\
99.98 \pm 0.21 \\
71.75 \pm 23.65^{a}\end{array}$ & 0.085 & $\begin{array}{c}31.87 \pm 0.16 \\
58.43 \pm 1.10 \\
75.62 \pm 0.91 \\
88.65 \pm 0.52 \\
99.25 \pm 0.22 \\
70.76 \pm 23.74^{a}\end{array}$ & 0.088 & $\begin{array}{c}33.62 \pm 0.51 \\
55.58 \pm 0.23 \\
79.63 \pm 0.04 \\
89.63 \pm 0.04 \\
99.70 \pm 0.23 \\
71.63 \pm 23.99^{a}\end{array}$ & 0.087 & $\begin{array}{r}18.23 \pm 0.41 \\
30.14 \pm 0.21 \\
43.08 \pm 0.21 \\
65.14 \pm 0.41 \\
80.88 \pm 1.04 \\
47.49 \pm 22.81^{\mathrm{b}}\end{array}$ & 0.258 \\
\hline $\begin{array}{l}\text { Dichloromethane } \\
\text { extract }\end{array}$ & $\begin{array}{c}0.05 \\
0.1 \\
0.25 \\
0.5 \\
1.0 \\
\text { Mean }\end{array}$ & $\begin{array}{c}23.05 \pm 0.22 \\
41.26 \pm 0.23 \\
66.02 \pm 0.22 \\
75.40 \pm 0.23 \\
95.21 \pm 0.11 \\
60.18 \pm 25.41^{b}\end{array}$ & 0.148 & $\begin{array}{c}25.62 \pm 1.26 \\
40.31 \pm 0.86 \\
55.1 \pm 1.12 \\
73.43 \pm 1.76 \\
86.56 \pm 0.88 \\
56.20 \pm 23.97^{b}\end{array}$ & 0.168 & $\begin{array}{c}23.67 \pm 0.04 \\
40.35 \pm 0.14 \\
59.28 \pm 0.28 \\
73.23 \pm 0.46 \\
91.93 \pm 0.09 \\
57.69 \pm 23.97^{b}\end{array}$ & 0.167 & $\begin{array}{c}11.25 \pm 0.10 \\
21.6 \pm 0.14 \\
31.98 \pm 0.31 \\
49.77 \pm 0.11 \\
64.48 \pm 0.11 \\
35.82 \pm 19.16^{c}\end{array}$ & 0.511 \\
\hline Hexane extract & $\begin{array}{c}0.05 \\
0.1 \\
0.25 \\
0.5 \\
1.0 \\
\text { Mean }\end{array}$ & $\begin{array}{c}11.7 \pm 0.22 \\
25.26 \pm 0.23 \\
43.87 \pm 0.23 \\
63.5 \pm 0.22 \\
90.7 \pm 0.07 \\
47.00 \pm 27.96^{c}\end{array}$ & 0.257 & $\begin{array}{c}15.31 \pm 0.78 \\
33.43 \pm 1.26 \\
52.18 \pm 1.15 \\
69.22 \pm 1.96 \\
83.75 \pm 0.36 \\
50.77 \pm 24.44^{\mathrm{C}}\end{array}$ & 0.221 & $\begin{array}{c}4.92 \pm 0.79 \\
33.80 \pm 0.14 \\
52.04 \pm 0.23 \\
72.17 \pm 0.46 \\
90.68 \pm 0.18 \\
50.72 \pm 29.80^{c}\end{array}$ & 0.306 & $\begin{array}{c}5.36 \pm 0.31 \\
13.67 \pm 0.21 \\
23.60 \pm 0.31 \\
30.88 \pm 1.04 \\
44.63 \pm 0.31 \\
23.63 \pm 13.61^{d}\end{array}$ & 1.45 \\
\hline $\begin{array}{l}\text { Ascorbic acid } \\
\text { (Standard) }\end{array}$ & $\begin{array}{c}0.05 \\
0.1 \\
0.25 \\
0.5 \\
1.0 \\
\text { Mean }\end{array}$ & $\begin{array}{c}38.42 \pm 1.06 \\
62.23 \pm 1.28 \\
82.34 \pm 1.99 \\
95.36 \pm 0.87 \\
99.48 \pm 0.11 \\
75.56 \pm 22.65^{a}\end{array}$ & 0.066 & $\begin{array}{c}32.89 \pm 1.80 \\
60.47 \pm 1.25 \\
77.50 \pm 1.90 \\
89.35 \pm 1.65 \\
98.83 \pm 2.05 \\
71.81 \pm 23.29^{a}\end{array}$ & 0.082 & $\begin{array}{r}31.50 \pm 0.96 \\
58.42 \pm 1.81 \\
75.54 \pm 0.53 \\
89.49 \pm 1.22 \\
99.89 \pm 0.93 \\
70.96 \pm 24.14^{\mathrm{a}}\end{array}$ & 0.081 & $\begin{array}{c}29.10 \pm 0.47 \\
46.27 \pm 0.74 \\
53.09 \pm 0.53 \\
68.90 \pm 0.46 \\
88.19 \pm 0.52 \\
57.11 \pm 20.11^{\mathrm{a}}\end{array}$ & 0.156 \\
\hline
\end{tabular}

Results were expressed as mean \pm SD.

Comparison were only amongst extracts for each methods and mean values in each method followed by same letter are non-significantly different ( $p>0.05)$ according to Tukey multiple range test 
The results of percentage scavenging of free radicals in present study were in consonance with the Stankovic [38] which reported that alcoholic extract of $P$. cattleianum exhibited the highest antioxidant activity and showed scavenging percentage of $94.57 \%$, followed by the aqueous extract $92.62 \%$. Also Chang et al. [39] reported that ethanol extract of $S$. lappa showed $95.02 \%$ inhibition which was comparable to that of their ascorbic acid positive control. In present studies methanolic extract was most active and showed comparable activity to that of standard in all the assays. The $\mathrm{IC}_{50}$ values of methanol were usually lower. Jananie et al. [40] also reported the lower $\mathrm{IC}_{50}$ hydro-alcoholic extract of Cynodon doctylon as compared to other solvent extract. Lower the $\mathrm{IC}_{50}$ values of treatment better is activity. Results were also in agreement with Sonawane et al. [41] who reported the positive correlation between radical scavenging activities with phenolic content. Similar trend was observed in present study as trend of activity was similar as the trend observed in case of total phenolic and flavonoidal content of extracts. It was observed that the total phenolic and flavonoid content varied with polarity of solvent used for making extract. The antioxidant activity also varied with phenolic and flavonoid content. Antioxidant potential can be related to the amount of phenols and flavonoids. Yingming et al. [42] reported that the antioxidant activity of phenolic compounds was due to their redox properties, which played an important role in absorbing and neutralizing free radicals, quenching singlet and triplet oxygen or decomposing peroxides and the antioxidant activity of flavonoid compounds was reported due to their scavenging or chelating process [43]. Also antioxidant activity of chickpea (Cicer arietinum L.) increased during roasting and was also related to Maillard reaction products formation [44]. Thus high antioxidant activity of roots could be related to the Maillard reaction products as well as high phenolics and flavonoid content.

\section{CONCLUSION}

It was found that even roasted roots of chicory were rich source of phenolics and flavonoids an still possess antioxidant potential. The roasted $C$. intybus roots extracts contained good amount of phenolic and flavonoid content and methanol extract exhibited antioxidant activity equivalent to ascorbic acid. The content of phenols, flavonoids and antioxidant activity of extracts were found to be greatly affected by type of solvent used for extraction, similarly it affected the antioxidant potential of extracts. It was found that most of phenols and flavonoids present in $C$. intybus roots are methanol soluble. The higher antioxidant capacity of methanol extract of $C$. intybus roots can be related to its higher phenolic and flavonoid content. An extract is considered to be active against free radicals if $\mathrm{IC}_{50}<5 \mathrm{mg} / \mathrm{mL}$ [45]. All the tested extracts showed $\mathrm{IC}_{50}$ values less than $0.6 \mathrm{mg} / \mathrm{mL}$, therefore roasted $C$. intybus root powder is also a very good source of antioxidants. Although GC-MS analysis showed that among volatile components 5-hydroxymethyl furfural was major component in extracts of roasted $C$. intybus root from India. HMF might be responsible for the strong flavour and aroma of roasted root powder. HMF was also reported to be genotoxic in some reports while not in others thus it could be a point of concern. Overall it could be concluded that roasted roots of chicory also possess phenolic and flavonoidal content and good antioxidant potential. Methanol is the best solvent for extraction of roasted roots for further search of bioactive components.

Conflict of interest: The authors declared that they have no conflict of interest.

\section{REFERENCES}

1. Baek $\mathrm{HH}$, Cadwallader KR. Roasted chicory aroma evaluation by gas chromatography/mass spectrometry/olfactometry. J Food Sci. 1998;63:234-7.

2. Willeman H, Hance P, Fertin A, Voedts N, Duhal N, Goossens JF, Hilbert JL. A method for the simultaneous determination of chlorogenic acid and sesquiterpene lactone content in industrial chicory root foodstuffs. Sci World J. 2014;2014:1-11. doi:10.1155/2014/583180.

3. Toneli JC, Fernanda EXM, Martinelli P, Dal Fabbro IM, Kil J. Optimization of a physical concentration process for inulin. J Food Eng. 2007;8:832-8. 
4. Quanzhen W, Cui J. Perspectives and utilization technologies of chicory (Cichorium intybus L.): A review. Afri J Biotech. 2011;10:1966-77.

5. De Mastro G, Manolio G, Marzi V. Jerusalem artichoke (Hellanthus tuberosus L.) and chicory (Cichorium intybus L.): Potential crops for inulin production in the Mediterranean area. Acta Hort. 2004;629:365-74.

6. Hui, Ru Y, Shaoh H, Yingli Y. The extraction and purification of inulin. Nat Prod Res Dev. 2002;14:65-9.

7. Dalar A, Konczak I. Cichorium intybus from Eastern Anatolia: Phenolic composition antioxidant and enzyme inhibitory activities. Ind Crop Prod. 2014;60:79-85.

8. Sinkovic L, Hribar J, Vidrih R. Influence of cultivar and storage of chicory (Cichorium intybus L.) plants on polyphenol composition and antioxidative potential. Czech J Food Sci. 2014;32:10-5.

9. Papetti A, Daglia M, Grisoli P, Dacarro C, Gregotti C, Gazzani G. Anti and pro-oxidant activity of Cichorium genus vegetables and effect of thermal treatment in biological systems. Food Chem. 2006;97:157-65.

10. Nandagopal S, Ranjitha Kumari BD. Phytochemical and antibacterial studies of chicory (Cichorium intybus L.)-A multipurpose medicinal plant. Adv Biol Res. 2007;1:17-21.

11. El-Sayed YS, Lebda MA, Hassinin M, Noeman SA. Retraction: Chicory (Cichorium intybus L.) root extract regulates the oxidative status and antioxidant gene transcripts in $\mathrm{CCl}_{4}$-induced hepatotoxicity. PLoS One. 2017;12:1-10. doi:10.1371/journal.pone.0173587.

12. Li R, Shang H, Wu H, Wang M, Duan M, Yang J. Thermal inactivation kinetics and effects of drying methods on the phenolic profile and antioxidant activities of chicory (Cichorium intybus L.) leaves. Sci Rep. 2018;8(1):9529. doi:10.1038/s41598-018-27874-4.

13. Morales P, Ferreira ICFR, Carvalho AM, Sánchez-Mata MC, Cámara M, Fernández-Ruiz V, Pardo-de-Santayana M, Tradío J. Mediterranean-cultivated vegetables as dietary sources of compounds with antioxidant and biological activity. LWT-Food Sci Technol. 2014;55:389-96.

14. Carazzone C, Mascherpa D, Gazzani G, Papetti A. Identification of phenolic constituents in red chicory salads (Cichorium intybus) by high-performance liquid chromatography with diode array detection and electrospray ionisation tandem mass spectrometry. Food Chem. 2013;138:106271.

15. Azay-Milhau J, Ferrare K, Leroy J, Aubaterre J, Tournier M, Lajoix AD, Tousch D. Antihyperglycemic effect of a natural chicoric acid extract of chicory (Cichorium intybus L.): a comparative in vitro study with the effects of caffeic and ferulic acids. J Ethnopharmacol. 2013;150(2):755-60.

16. Singh R, Chahal KK. Phytochemical analysis and in vitro antioxidant capacity of different solvent extracts of Saussurea lappa L. roots. J Pharma Phytochem. 2018;7(3);427-32.

17. Lachman, J.; Hamouz, K.; Orsak, M.; Pivec, V. Potato tubers as a significant source of antioxidant human nutrition. Plant Soil Environ 2000 46, 231-236.

18. Eom SH, Cheng WJ, Hyoung JP, Kim EH, Chung MI, Kim MJ, Yu CY, Cho DH. Far infrar-red ray irradiation stimulates antioxidant activity in Vitis flexuosa thunb berries. Korean J Med Crop Sci. 2007;15:319-23.

19. Benzie IFF, Strain JJ. The ferric reducing ability of plasma (FRAP) as a measure of antioxidant power: The FRAP assay. Anal Biochem. 1996;239:70-6.

20. Liyana PCM, Shahidi F. Antioxidant activity of commercial soft and hard wheat (Triticum aestivum L.) as affected by gastric pH conditions. J Agric Food Chem. 2005;53:2433-40.

21. Halliwell B, Gutteridge JMC, Aruoma OI. The deoxyribose method: A simple test tube assay for determination of rate constants for reactions of hydroxyl radical. Anal Biochem. 1987;95:351-8.

22. Green LC, Wagner DA, Glogowski J, Skipper PL, Wishnok JS, Tannenbaum SR. Analysis of nitrate, nitrite and $\left({ }^{15} \mathrm{~N}\right)$ nitrates in biological fluids. Anal Biochem. 1982;126:131-3.

23. Liu F, Ooi VEC, Chang ST. Free radical scavenging activity of mushroom polysaccharide extracts. Life Sci. 1997;60:763-71.

24. Murkovic M, Pichler N. Analysis of 5-hydroxymethylfurfural in coffee, dried fruits and urine. Mol Nutr Food Res. 2006;50:842-6.

25. Majcher AM, Klensporf-pawlik D, Dziadas $\mathrm{M}$, Jelen $\mathrm{HH}$. Identification of aroma active compounds of cereal coffee brew and its roasted ingredients. J Agric Food Chem. 2013;61:2648-54. 
26. Fachri BA, Abdilla RM, Rasrendra CB, Heeres HJ. Experimental and modelling studies on the uncatalysed thermal conversion of inulin to 5-hydroxymethylfurfural and levulinic acid. Sustainable Chem Processes. 2015;3:1-12.

27. Lee YC, Shlyankevich M, Jeong HJ, Heong HK, Douglas J, Surh YJ. Bioactivation of 5hydroxymethylfurfural to an electrophilic and mutagenic allylic sulphuric acid ester. Biochem Biophys Res Comm. 1995;209:995-1002.

28. Glatt HR, Sommer Y. Health risks by 5-hydroxymethylfurfural (HMF) and related compounds. In: Acrylamide and other Health Hazardous Compounds in Heat-Treated Foods. Skog K, Alexander J, editors. Cambridge: Woodhead Publishing; 2006. p. 328-53.

29. Ulbricht RJ, Northup SJ, Thomas JA. A review of 5-hydroxymethyl furfural (HMF) in parenteral solutions. Fundam Appl Toxicol. 1984;4:843-53.

30. Janzowski C, Glaab V, Samimi E, Schlatter J, Eisenbrand G. 5-Hydroxymethylfurfural: Assessment of mutagenicity, DNA-damaging potential and reactivity towards cellular glutathione. Food Chem Toxicol. 2000;38:801-9.

31. Godfrey VB, Chen LJ, Griffin RJ, Lebetkin EH, Burka LT. Distribution and metabolism of 5hydroxymethylfurfural in male $\mathrm{F} 344$ rats and B6C3F1 mice after oral administration. J Toxicol Environ Health A. 1999;57:199-210.

32. Jellum E, Borresen HC, Eldjarn L. Presence of furane derivatives in patients receiving fructosecontaining solutions intraveneously. Clin Chim Acta. 1973;47:191-201.

33. Felhi S, Daoud A, Hajlaoui H, Mnafgui K, Gharsallah N, Kadri A. Solvent extraction effects on phytochemical constituents profiles, antioxidant and antimicrobial activities and functional group analysis of Ecballium elaterium seeds and peels fruits. Food Sci Technol. 2017;37:483-92.

34. Baeza G, Sarriá B, Bravo L, Mateos R. Polyphenol content, in vitro bioaccessibility and antioxidant capacity of widely consumed beverages. J Sci Food Agric. 2017;98:1397-406.

35. Gorjanovic S, Komes D, Petronijevic JL, Pastor FT, Cvitanovic AB, Veljovic M, Pezo L, Suznjevic ZD. Antioxidant efficiency of polyphenols from coffee and coffee substitutes-electrochemical versus spectrophotometric approach. J Food Sci Technol. 2017;54:2324-31.

36. Rajurkar NS, Hande SM. Estimation of phytochemical content and antioxidant activity of some selected traditional Indian medicinal plants. Indian J Pharmaceut Sci. 2011;73:146-51.

37. Zhang YJ, Gan RY, Li S, Zhou Y, Li AN, Xu DP, Li HB. Antioxidant phytochemicals for the prevention and treatment of chronic diseases. Molecules. 2015;20:21138-56.

38. Stankovic MS. Total phenolic content, flavonoid concentration and antioxidant activity of Marrubium peregrinum L. extracts. Kragujevac J Sci. 2011;33:63-72.

39. Chang KM, Choi SI, Kim GH. Anti-oxidant activity of Saussurea lappa C.B. Clarke roots. Prev Nutr Food Sci. 2012;17:306-9.

40. Jananie RK, Priya V, Vijaylasksmi K. In vitro assessment of free radical scavenging activity of cynodondactylon. J Chem Pharm Res. 2001;3:647-54.

41. Sonawane I, Dhasade V, Nirmal S. Antioxidant effect of Tephrosia purpurea L. roots. Int J Pharm Sci Res. 2010;1:57-60.

42. Yingming P, Ping L., Hengshan, W., Min, L. Antioxidant activities of several chinese medicinal herbs. Food Chem. 2004;88:347-50.

43. Cook NC, Samman S. Flavonoids: Chemistry, metabolism, cardioprotective effects and dietary sources. Nutr Biochem. 1996;7:66-76.

44. Segev A, Badani H, Galili L, Hovav R, Kapulnik Y, Shomer I, Galili S. Effects of baking roasting and frying on total polyphenols and antioxidant activity in colored chickpea seeds. Food Nutr Sci. 2012;3:369-76.

45. Abdillah S, Tambunan RM, Farida Y, Sandhiutami NMD, Dewi RM. Phytochemical screening and antimalarial activity of some plants traditionally used in Indonesia. Asian Pac J Trop Dis. 2015;5:454-7.

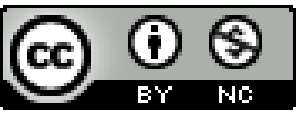

(C) 2018 by the authors. Submitted for possible open access publication under the terms and conditions of the Creative Commons Attribution (CC BY NC) license (https://creativecommons.org/licenses/by-nc/4.0/). 
